\title{
Quality of Life Assessment in Post-Stroke Patients
}

Ocena jakości życia pacjentów po przebytym udarze mózgu

\author{
Anna Pacian', Teresa B. Kulik', Joanna Bednarz², Monika Kaczoruk', \\ Ewa Kawiak-Jawor ${ }^{1}$
}

'Katedra Zdrowia Publicznego, Wydział Nauk o Zdrowiu, Uniwersytet Medyczny w Lublinie/ Chair of Public Health, Faculty of Health Sciences, Medical University of Lublin 2Absolwentka Kierunku Pielęgniarstwo, Wyższa Szkoła Biznesu i Przedsiębiorczości w Ostrowcu Świętokrzyskim, Wydział Pedagogiki i Nauk o Zdrowiu/ Graduate of Nursing, College of Business and Entrepreneurship in Ostrowiec Świętokrzyski, Faculty of Pedagogy and Health Sciences

\author{
AUTOR DO KORESPONDENCJI/CORRESPONDING AUTHOR: \\ Monika Kaczoruk \\ Katedra Zdrowia Publicznego, Wydział Nauk o Zdrowiu \\ Uniwersytet Medyczny w Lublinie, \\ ul. Chodźki 1 (Collegium Universum), 20-093 Lublin \\ tel. +4881448 6720 \\ e-mail: monikakaczoruk@umlub.pl
}

STRESZCZENIE OCENA JAKOŚCI ŻYCIA PACJENTÓW PO PRZEBYTIYM UDARZE MÓZCO

Cel. Analiza jakości życia pacjentów po udarze mózgu leczonych na Oddziale Neurologii w Powiatowym Szpitalu Specjalistycznym. Materiał i metodyka. Badaniem objęto 80 osób po przebytym udarze mózgu leczonych w Oddziale Neurologii Powiatowego Szpitala Specjalistycznego. Do badań wykorzystano metodę sondażu diagnostycznego, technikę ankiety oraz wystandaryzowane narzędzie badawcze: polską wersję kwestionariusza ankiety Skali Jakości Życia po Udarze Mózgu (SJŻUM), autorstwa Williams i wsp. Skala obejmowała 12 podskal oraz wynik ogólny, z których wszystkie mieściły się zakresie 1-5 pkt. - wyższym wynikom odpowiadała wyższa jakość życia. Weryfikacji różnic między zmiennymi dokonano przy użyciu nieparametrycznych testów. Przyjęto poziom istotności $p<0,05$.

Wyniki. Jakość życia pacjentów po udarze mózgu jest na poziomie 2,64 pkt czyli poniżej przeciętnej, za którą przyjęto środek skali 1-5pkt. Ogólna jakość życia była wyższa wśród kobiet $(3,02)$ niż wśród mężczyzn (2,39). Pacjenci po udarze niedokrwiennym posiadali istotnie wyższą jakość życia (na poziomie 2,83) niż pacjenci po udarze krwotocznym (na poziomie 2,23).

Wnioski. Problemem chorych po udarze mózgu jest nie tylko ograniczenie sprawności ruchowej będące następstwem niedowładu. Identyfikacja zaburzeń bio-psycho-społecznych i pomoc w ich przezwyciężaniu może diametralnie zmienić sytuację chorego. Ocena jakości życia jest zadaniem koniecznym, ponieważ umożliwia ocenę stanu chorego, nie tylko pod kątem skuteczności terapii, ale przede wszystkim pod względem możliwości poprawy jakości funkcjonowania chorego, w aspekcie psychicznym oraz społecznym.

Słowa kluczowe: jakość życia, udar mózgu, pacjent, patomechanizm udaru, badania ankietowe

ABSTRACT QUALITY OF LIFEASSESSMENT IN POST-STROKE PATIENIS

Aim. Presentation of quality of life of post-stroke patients treated in the Neurology Ward of the District Specialist Hospital.

Material and methods. The research covered 80 patients after stroke, treated in the Neurology Ward of the District Specialist Hospital. The study used the diagnostic survey method, the questionnaire technique and the standardized research tool: the Polish version of the Stroke-Specific Quality of Life Scale (SS-Q0L), authored by Williams et al. The scale comprised 12 subscales and an overall result, all of which ranged between 1 and 5 points. Higher scores corresponded to higher quality of life. Differences between the variables were verified with nonparametric tests. The significance level was established at $p<0.05$.

Results. Quality of life of post-stroke patients treated in the Neurology Ward of the District Specialist Hospital was at the level of 2.64 , that is below the average established in the middle of the 1-5 scale. The overall quality of life was higher among women (3.02) than among men (2.39). Patients after ischemic stroke had significantly higher quality of life (at the level of 2.83) than patients after hemorrhagic stroke (at 2.23).

Conclusions. The problem of patients after stroke is not only limitation of mobility due to paresis. Identification of bio-psycho-social disorders and help in overcoming them can radically change the patient's situation. The assessment of quality of life is an indispensable task because it enables evaluation of the patient's condition, not only in terms of effectiveness of therapy, but above all, in terms of a possibility for improvement of the patient's quality of functioning, in the mental and social aspects.

Key words: quality of life, stroke, patient, stroke pathomechanism, survey research 


\section{INTRODUCTION}

The interest in quality of life originated in the 1970 s owing to Cambell who is considered a pioneer of research on quality of life. However, the notion of quality of life itself emerged in 1990 [1]. The multidimensional approach to quality of life can be found in a definition provided by the World Health Organization (WHO) according to which quality of life is the individual's perception of their position in life in the context of the culture and value systems in which they live and in relation to their goals, expectations, standards and concerns [2].

On the basis of the cited definition of quality of life suggested by the WHO, the quality of life assessment was extended to encompass not only physical but also mental condition, as well as social relations, environment, religion, beliefs and convictions. [3]. Quality of life assessment can be regarded as a view of an individual's life situation which refers to a fragment of his or her life and is compared to a specific model desired by this person. It is also a difference between hopes and expectations of an individual and his or her current experiences.

Research on quality of life is an interdisciplinary issue which combines clinical and psychological aspects. The goals connected with enhancement of a patient's comfort of living become important. A stroke impairs quality of life in the functional and mental dimensions. The focus on therapeutical results is not the sole purpose of treatment. This is due to so-called non-medical aims understood as improvement on a patient's wellbeing which influences his or her functioning in the society.

Decreased quality of life is an effect of the central nervous system injury. It reduces self-reliance in everyday life activities, leads to disability and dependence on other people. Lower quality of life after stroke is caused mostly by impaired physical fitness, emotional disturbances and lack of social support. Problems with independent performance of basic everyday life activities, sometimes loss of the previous social status and lack of the family support result in growing isolation of a patient from the outside world and deterioration in social relations. Identification of all limitations and helping a patient overcome his or her problems can radically change the his/her situation [4].

The authors' review of literature on the subject and their own research on quality of life in post-stroke patients open the way to further, multidimensional analyses. Research on quality of life should take into account physical and psychological aspects, as well as relationships within the community and the environment.

\section{AIM}

The primary objective of the study was to analyse quality of life in post-stroke patients treated in the Neurology Ward of the District Specialist Hospital.

Quality of life was analysed in terms of the influence of socio-demographic factors, type of stroke, type of paresis, length of rehabilitation, and time passed since stroke.

\section{MATERIALS AND METHODS}

A group of 80 patients treated in the Neurology Ward of the Specialist Hospital were qualified for the study. The research was conducted from April to May 2017. A part of the respondents filled in the questionnaires on their own, with no assistance of an interviewer, few patients were helped by an interviewer. The selection criteria for the study were fulfilled by patients after stroke, qualified on the basis of medical documentation. The respondents were informed about the purpose of the research. Each of the respondents gave his or her written consent to the survey. Prior to the survey, the consent was also given by the Head of the Hospital. The provisions of the Declaration of Helsinki were followed in the research.

The study uses the Polish version of the Stroke-Specific Quality of Life Scale (SS-QOL), authored by Williams et al. from the Indiana University School of Medicine in Indianapolis [5]. The cultural adaptation of the scale to the Polish version was prepared by A. Bejer and A. Kwolek [6]

The scale enables establishment of a quality of life profile within 12 subscales, that is: self-care (S), vision (V), language (L), mobility (M), work (W), upper extremity function (UE), thinking (T), personality (P), mood (M), family roles (FR), social roles (SR), energy (E). Each subscale contains from 3 to 6 items, 49 altogether. The scale has two sets of answers which should be given in accordance with the condition observed by the patient during the week preceding the survey. The scale comprises 12 subscales and an overall result, all of them within the range of the 5-level Likert scale where higher scores correspond to better functioning $[5,6,7]$.

The research material was analysed with MannWhitney and Kruskal-Wallis statistical tests. The significance level was established at $\mathrm{p}<0.05$. Calculations were made with the statistical software: IBM SPSS Statistics 24.0 PL.

\section{RESULTS}

The surveyed group comprised 80 patients. Over a half of them $(61.3 \%)$ were male ( 49 men), whereas 31 female participants accounted for $38.8 \%$ of the respondents. Most of the respondents $(73.8 \%)$ were senior citizens. The most numerous age group were people between 61 and $70(43.8 \%)$, while $22.5 \%$ of the respondents were between 71 and 80 , and $16.3 \%$ of people were between 41-50 years old. Few respondents were between 51 and 60 (7.5\%), 81-90 (7.5\%) and 30-40 (2.5\%) years old.

The overall quality of life of the surveyed respondents was at the level of 2.64 points $(\mathrm{SD}=0.84)$. The results ranged between 1.08 and 4.42 points and a half of the respondents scored below 2.98 . The overall quality of life was below the average which was established in the middle of the 1-5 point scale, that is 3 points. This is presented in Tab. 1. 
Tab. 1. Quality of life of the respondents.

\begin{tabular}{|l|c|c|c|c|c|}
\hline & Average & Median & SD & Min & Max \\
\hline Self-care & 2.69 & 3.00 & 1.03 & 1.00 & 4.60 \\
\hline Vision & 3.26 & 3.00 & 1.05 & 2.00 & 5.00 \\
\hline Language & 3.13 & 3.00 & 1.04 & 1.25 & 5.00 \\
\hline Mobility & 2.84 & 3.00 & 1.03 & 1.00 & 5.00 \\
\hline Work & 2.70 & 3.00 & 0.99 & 1.00 & 4.33 \\
\hline $\begin{array}{l}\text { Upper extremity } \\
\text { function }\end{array}$ & 2.58 & 2.20 & 1.11 & 1.00 & 4.60 \\
\hline Thinking & 2.32 & 2.33 & 0.90 & 1.00 & 4.00 \\
\hline Personality & 2.58 & 3.00 & 1.15 & 1.00 & 5.00 \\
\hline Mood & 2.61 & 2.60 & 0.89 & 1.00 & 4.80 \\
\hline Family roles & 2.55 & 3.00 & 0.99 & 1.00 & 5.00 \\
\hline Social roles & 2.11 & 2.20 & 0.79 & 1.00 & 4.60 \\
\hline Energy & 2.26 & 2.33 & 0.85 & 1.00 & 4.33 \\
\hline Overall quality of life & 2.64 & 2.98 & 0.84 & 1.08 & 4.42 \\
\hline
\end{tabular}

Quality of life of post-stroke patients was the highest with respect to vision (3.26). Quality of life connected with language (3.13) and mobility (2.84) was at the average level. Post-stroke patients demonstrated significantly decreased quality of life in terms of self-care (2.69), mood (2.61), personality (2.58), upper extremity function (2.58), and family roles (2.55). The lowest quality of life was observed with respect to thinking (2.32), energy (2.26) and social roles (2.11).

The analysis of quality of life with regard to sex of the surveyed respondents indicated that women had significantly higher quality of life in comparison to men in the following spheres: self-care (3.06), vision (3.70), mobility (3.32), work (3.11), upper extremity function (3.05), thinking (2.69), family roles (3.01), social roles (2.51) and energy (2.60). Moreover, the overall quality of life was higher in women (3.02) than in men (2.39). This is presented in Tab. 2 .

Tab. 2. Quality of life according to sex of the respondents.

\begin{tabular}{|l|c|c|c|c|c|}
\hline \multirow{2}{*}{ Sex } & \multicolumn{2}{|c|}{ Women } & \multicolumn{2}{c|}{ Men } & \multirow{2}{*}{ p } \\
\cline { 2 - 5 } & Average & SD & Average & SD & \\
\hline Self-care & 3.06 & 0.96 & 2.46 & 1.02 & $\mathbf{0 . 0 3 0 2}$ \\
\hline Vision & 3.70 & 0.83 & 2.99 & 1.08 & $\mathbf{0 . 0 0 2 4}$ \\
\hline Language & 3.43 & 0.75 & 2.95 & 1.15 & 0.0555 \\
\hline Mobility & 3.32 & 0.92 & 2.53 & 0.99 & $\mathbf{0 . 0 0 6 4}$ \\
\hline Work & 3.11 & 0.84 & 2.44 & 1.00 & $\mathbf{0 . 0 0 3 1}$ \\
\hline $\begin{array}{l}\text { Upper extremity } \\
\text { function }\end{array}$ & 3.05 & 1.08 & 2.28 & 1.03 & $\mathbf{0 . 0 0 5 7}$ \\
\hline Thinking & 2.69 & 0.75 & 2.09 & 0.92 & $\mathbf{0 . 0 0 6 2}$ \\
\hline Personality & 3.02 & 0.86 & 2.30 & 1.23 & 0.0825 \\
\hline Mood & 2.76 & 0.79 & 2.52 & 0.95 & 0.5681 \\
\hline Family roles & 3.01 & 0.60 & 2.25 & 1.07 & $\mathbf{0 . 0 0 0 2}$ \\
\hline Social roles & 2.51 & 0.76 & 1.85 & 0.70 & $\mathbf{0 . 0 0 0 9}$ \\
\hline Energy & 2.60 & 0.53 & 2.05 & 0.94 & $\mathbf{0 . 0 2 7 2}$ \\
\hline Overall quality of life & 3.02 & 0.63 & 2.39 & 0.87 & $\mathbf{0 . 0 0 1 9}$ \\
\hline
\end{tabular}

Quality of life connected with work $(\mathrm{p}<0.05)$ and upper extremity function $(\mathrm{p}<0.05)$ deteriorated significantly along with the growing age of the respondents. People aged 61-70 had significantly lower quality of life with respect to thinking (1.97), mood (2.29) and family roles (1.98) compared to other respondents. On the other hand, no significant correlation was observed between the patients' overall quality of life and their age.

An important element contributing to high quality of life is also the occupational status. The majority of the respondents $(67.5 \%)$ stated that there was no chance to return to their previous occupation. A minimal chance of returning to the previously pursued occupation was seen by $31.3 \%$ of the patients, whereas only $1.3 \%$ of the respondents evaluated their occupational status positively. This is presented in Fig. 1.

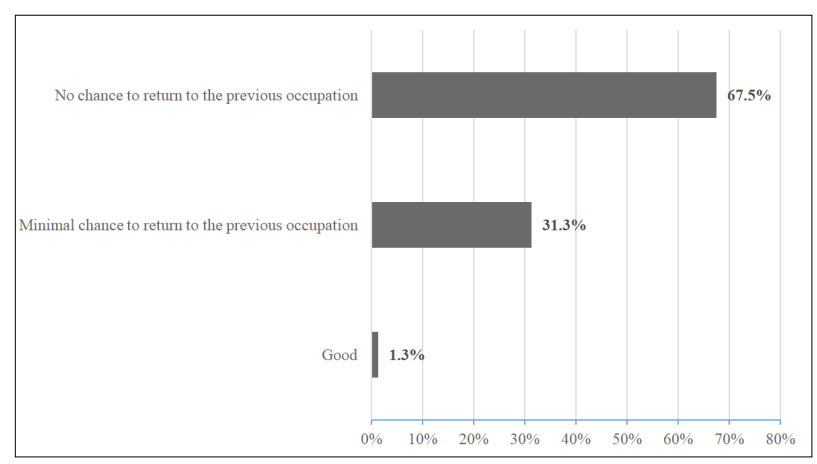

Fig 1. Assessment of one's own occupational status.

The majority of the patients $(95.0 \%)$ did not return to professional activity after stroke, whereas $1.3 \%$ of the respondents returned to professional activity within 1 month since stroke, and $3.8 \%$ returned to professional activity within more than a year. This is presented in Fig. 2.

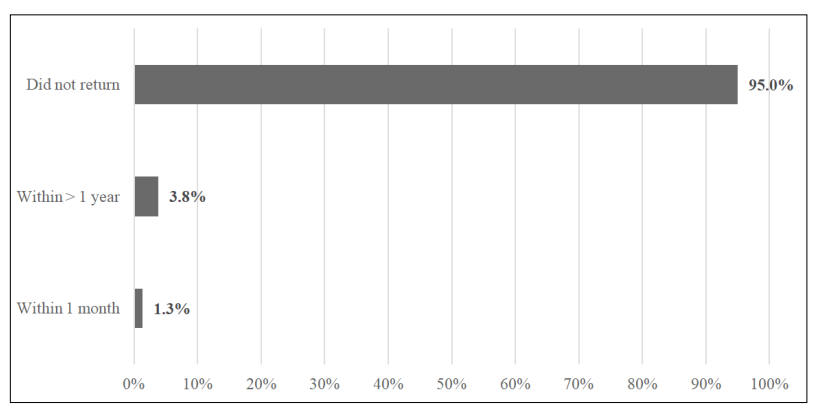

Fig 2. Return to professional activity after stroke.

Ischemic stroke occurred in $67.5 \%$ of the patients, while $32.5 \%$ suffered from hemorrhagic stroke. A half of the patients $(50.0 \%)$ had a right-sided stroke and the other half suffered from a left-sided stroke. It was the first stroke for the majority of the patients (63.8\%), while $28.8 \%$ of the respondents had a stroke for the second time, and $7.5 \%$ for the third time.

The statistical analysis demonstrated that patients after ischemic stroke had significantly higher quality of life than patients after hemorrhagic stroke. These differences pertained to quality of life in the following spheres: self-care (2.88), vision (3.59), language (3.37), mobility (3.04), 
thinking (2.50), personality (3.03), mood (2.79), family roles (2.75) and energy (2.55). The overall quality of life was also significantly higher among people after ischemic stroke (2.83) than after hemorrhagic stroke (2.23). This is presented in Tab. 3.

Tab. 3. Quality of life and the type of stroke.

\begin{tabular}{|l|c|c|c|c|c|}
\hline \multirow{2}{*}{ Type of stroke } & \multicolumn{2}{|c|}{ Ischemic } & \multicolumn{2}{c|}{ Hemorrhagic } & \multirow{2}{*}{ p } \\
\cline { 2 - 5 } & Average & SD & Average & SD & \\
\hline Self-care & 2.88 & 0.94 & 2.30 & 1.13 & $\mathbf{0 . 0 0 9 5}$ \\
\hline Vision & 3.59 & 0.89 & 2.58 & 1.03 & $<\mathbf{0 . 0 0 0 1}$ \\
\hline Language & 3.37 & 0.98 & 2.64 & 0.99 & $\mathbf{0 . 0 0 1 0}$ \\
\hline Mobility & 3.04 & 0.86 & 2.42 & 1.24 & $\mathbf{0 . 0 2 7 2}$ \\
\hline Work & 2.85 & 0.86 & 2.40 & 1.19 & 0.0906 \\
\hline $\begin{array}{l}\text { Upper extremity } \\
\text { function }\end{array}$ & 2.64 & 1.04 & 2.44 & 1.25 & 0.2645 \\
\hline Thinking & 2.50 & 0.77 & 1.95 & 1.04 & $\mathbf{0 . 0 1 3 4}$ \\
\hline Personality & 3.03 & 0.91 & 1.64 & 1.04 & $<\mathbf{0 . 0 0 0 1}$ \\
\hline Mood & 2.79 & 0.82 & 2.25 & 0.95 & $\mathbf{0 . 0 0 4 7}$ \\
\hline Family roles & 2.75 & 0.83 & 2.12 & 1.14 & $\mathbf{0 . 0 0 5 6}$ \\
\hline Social roles & 2.17 & 0.69 & 1.98 & 0.97 & 0.2067 \\
\hline Energy & 2.55 & 0.64 & 1.67 & 0.93 & $<\mathbf{0 . 0 0 0 1}$ \\
\hline Overall quality of life & 2.83 & 0.69 & 2.23 & 0.98 & $\mathbf{0 . 0 0 9 4}$ \\
\hline
\end{tabular}

The study also examined quality of life in terms of the patients' self-reliance. When it somes to $41.3 \%$ of the patients, they were independent with respect to using toilet, whereas $58.8 \%$ of the respondents went to toilet assisted by another person. This is presented in Fig. 3 .

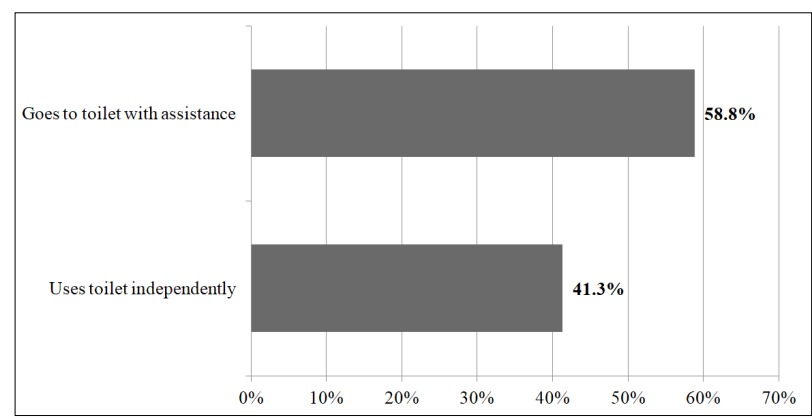

Fig 3. Independence of patients with respect to using toilet.

Quality of life in the sphere of self-care can be improved with rehabilitation. A group of $41.3 \%$ of the respondents exercised regularly, assisted by family. On the other hand, $30.0 \%$ of the patients exercised regularly on their own, and $28.8 \%$ exercised with a physiotherapist.

Patients who exercised all the time with help of their families had significantly higher quality of life with respect to vision (3.79), language (3.73), mobility (3.10), upper extremity function (2.86), thinking (2.68), mood (2.96), family roles (3.01) and energy (2.58) in comparison to people exercising on their own or with a physiotherapist. The overall quality of life was also higher in patients exercising all the time with family (2.93) than in the respondents exercising on their own (2.45) or with a physiotherapist (2.40) This is presented in Tab. 4.
Tab. 4. Quality of life of the respondents and length of rehabilitation.

\begin{tabular}{|l|c|c|c|c|c|c|c|}
\hline \multirow{2}{*}{$\begin{array}{l}\text { Length of } \\
\text { rehabilitation }\end{array}$} & \multicolumn{2}{|c|}{$\begin{array}{c}\text { I exercise all } \\
\text { the time with } \\
\text { a physiotherapist }\end{array}$} & \multicolumn{2}{|c|}{$\begin{array}{c}\text { I exercise all } \\
\text { the time } \\
\text { with family }\end{array}$} & \multicolumn{2}{|c|}{$\begin{array}{c}\text { I exercise all } \\
\text { the time } \\
\text { on my own }\end{array}$} & \multirow{2}{*}{ p } \\
\cline { 2 - 7 } & Average & SD & Average & SD & Average & SD & \\
\hline Self-care & 2.56 & 0.99 & 2.92 & 1.15 & 2.50 & 0.88 & 0.1331 \\
\hline Vision & 3.00 & 0.78 & 3.79 & 1.17 & 2.79 & 0.78 & $\mathbf{0 . 0 0 1 1}$ \\
\hline Language & 2.65 & 0.57 & 3.73 & 0.99 & 2.78 & 1.06 & $\mathbf{0 . 0 0 0 2}$ \\
\hline Mobility & 2.63 & 0.88 & 3.10 & 1.09 & 2.67 & 1.04 & $\mathbf{0 . 0 2 7 3}$ \\
\hline Work & 2.54 & 0.82 & 2.84 & 1.06 & 2.67 & 1.05 & 0.3280 \\
\hline $\begin{array}{l}\text { Upper } \\
\text { extremity } \\
\text { function }\end{array}$ & 2.02 & 0.61 & 2.86 & 1.26 & 2.73 & 1.10 & $\mathbf{0 . 0 4 1 6}$ \\
\hline Thinking & 2.03 & 0.83 & 2.68 & 0.77 & 2.11 & 1.00 & $\mathbf{0 . 0 1 0 8}$ \\
\hline Personality & 2.55 & 1.05 & 2.74 & 1.10 & 2.39 & 1.33 & 0.4506 \\
\hline Mood & 2.17 & 1.00 & 2.96 & 0.47 & 2.55 & 1.06 & $\mathbf{0 . 0 0 2 6}$ \\
\hline Family roles & 2.35 & 1.00 & 3.01 & 0.79 & 2.10 & 0.98 & $\mathbf{0 . 0 0 0 7}$ \\
\hline Social roles & 2.23 & 0.78 & 2.15 & 0.70 & 1.93 & 0.90 & 0.5069 \\
\hline Energy & 2.19 & 0.90 & 2.58 & 0.69 & 1.90 & 0.87 & $\mathbf{0 . 0 0 3 2}$ \\
\hline $\begin{array}{l}\text { Overall quality } \\
\text { of life }\end{array}$ & 2.40 & 0.73 & 2.93 & 0.77 & 2.45 & 0.93 & $\mathbf{0 . 0 0 4 8}$ \\
\hline
\end{tabular}

A high percentage of the respondents did not participate in rehabilitation exercises. Discouragement was the most frequent factor contributing to reluctance to exercise $(25.0 \%)$. Tiredness was mentioned in the second place $(17.5 \%)$ and depression in the third (16.3\%). Lack of faith in recovery was indicated by $12.5 \%$ of the respondents, whereas $10.0 \%$ of the patients pointed to their reluctance to burden family members with their disability. Only $18.8 \%$ of the respondents eagerly participated in rehabilitation. This is presented in Fig. 4.

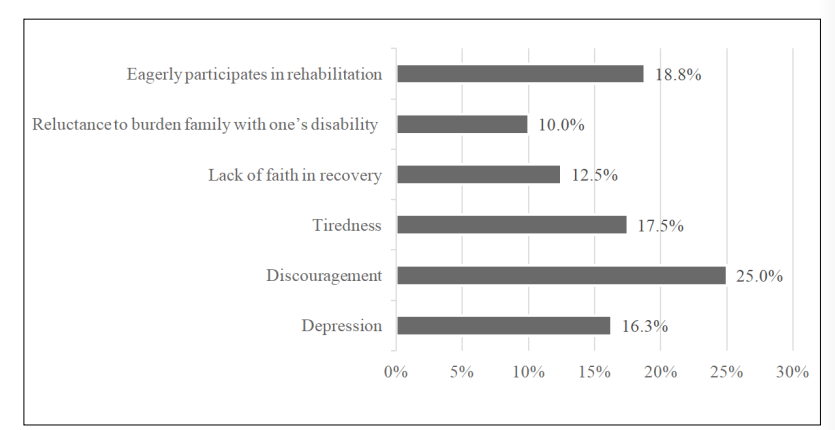

Fig 4. Factors contributing to unwillingness to exercise.

The respondents who made an effort connected with rehabilitation were also asked about its effectiveness and $83.8 \%$ of them answered positively. Improved motor activity as a result of rehabilitation was observed by $53.8 \%$ of the respondents and better mental condition was noticed by $51.3 \%$ of the patients who actively participated in rehabilitation exercises. Few people reported no improvement whatsoever (6.3\%) or enhancement of all aspects of functioning as a result of rehabilitation. The results did not sum up to $100 \%$ because the respondents indicated more than one answer. This is presented in Fig. 5. 


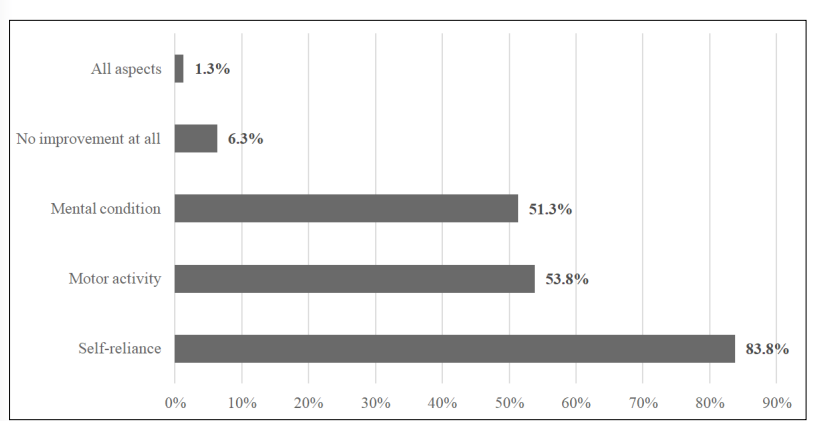

Fig 5. Influence of rehabilitation on improvement in the selected aspects of functioning.

Numerous studies indicate that the time which passed since stroke is a factor determining quality of life in post-stroke patients $[8,9]$. In the case of $10.0 \%$ of the patients 8-14 days passed since stroke. In a group of $16.3 \%$ of the respondents, stroke occurred 15-30 days before. The majority (61.3\%) of the patients had a stroke 31-90 days before. In a group of $12.5 \%$ of the patients, more than 90 days passed since stroke. The authors' own research showed that the patients' quality of life in the personality sphere decreased significantly along with passage of time. The highest quality of life in this aspect was presented by people who had a stroke 8-14 days before (3.38), whereas the lowest quality of life was demonstrated by the respondents who had a stroke more than 90 days before (1.63). The patients who had a stroke 8-14 days before, presented significantly lower quality of life with respect to social roles (1.63) in comparison to other respondents with a longer period of time since stroke. However, the overall quality of life did not depend significantly on the time which passed since stroke. This is presented in Tab. 5 .

\section{DISCUSSION}

Consequences of stroke include numerous complications, mainly neurological deficits [10]. In some patients stroke is reversible and does not cause any complications. However, it leads to permanent disability and decreased quality of life in ca. $25 \%$ of patients [11]. The complica- tion which decreases quality of life of post-stroke patients to the largest extent is motor disability, usually occurring as a consequence of hemiparesis, incorrect distribution of muscular tone. It is possible to prevent them through early commenced and correctly managed rehabilitation [12]. Quality of life can be improved by rehabilitation, which was demonstrated in a study by Hopman et al. [13]. The authors' own research indicated that motor activity was improved in $53.8 \%$ of the patients as a result of rehabilitation, whereas the mental condition got better in $51.3 \%$ of the patients who participated actively in rehabilitation exercises. Few respondents mentioned no improvement whatsoever $(6.3 \%)$ or enhancement of all aspects of functioning as a result of rehabilitation.

The overall quality of life of the patients did not depend significantly on the time which passed since stroke. In his study of a group of 96 post-stroke patients, Aschilo found that quality of life was deteriorating constantly and lastingly in 77 patients [14]. On the other hand, Niemi et al. observed that quality of life deteriorated after some time since stroke [15]. A study by J. Rykała et al. indicated that quality of life of post-stroke patients was considerably influenced by the consequences related to CNS injury, but also by the time which passed since stroke [16].

The analysis of the research results showed that quality of life after stroke was higher among women than among men. Similar conclusions can be drawn from a study by Baumann et al. Having assessed quality of life of 94 post-stroke patients - citizens of Luxembourg - with Newsqol questionnaire, they reported significantly higher quality of life among women [17]. However, a study by Zawadzka et al., [18] based on SS-QOL, indicated that sex did not significantly influence quality of life after stroke in any of the analysed spheres. On the other hand, a study by Carod-Artal et al., based on SIP scale, demonstrated lower quality of life of the women in Spain, who - however were in a worse neurological and functional condition and were older in comparison to men [19].

In the context of the analysis of quality of life depending on the patient's age, similar conclusions can be

Tab. 5. Quality of life and time since stroke.

\begin{tabular}{|l|c|c|c|c|c|c|c|c|c|}
\hline \multirow{2}{*}{ Time since stroke } & \multicolumn{2}{|c|}{$\mathbf{8 - 1 4}$ days } & \multicolumn{2}{c|}{$\mathbf{1 5 - 3 0}$ days } & \multicolumn{2}{c|}{$\mathbf{3 1 - 9 0}$ days } & \multicolumn{2}{c|}{ More than $\mathbf{9 0}$ days } & \multirow{2}{*}{ p } \\
\cline { 2 - 10 } & Average & SD & Average & SD & Average & SD & Average & SD & \multicolumn{1}{|c|}{ SD } \\
\hline Self-care & 2.48 & 0.72 & 2.92 & 1.04 & 2.73 & 0.88 & 2.38 & 1.79 & 0.5240 \\
\hline Vision & 2.88 & 0.17 & 3.46 & 0.52 & 3.31 & 1.14 & 3.10 & 1.45 & 0.4200 \\
\hline Language & 2.63 & 0.52 & 3.00 & 0.00 & 3.32 & 1.18 & 2.80 & 1.07 & 0.2077 \\
\hline Mobility & 2.31 & 0.95 & 3.08 & 0.09 & 2.99 & 1.00 & 2.20 & 1.55 & 0.0854 \\
\hline Work & 2.25 & 1.04 & 3.00 & 0.00 & 2.80 & 0.94 & 2.20 & 1.55 & 0.3448 \\
\hline Upper extremity function & 2.25 & 1.04 & 2.09 & 0.10 & 2.83 & 1.10 & 2.22 & 1.63 & 0.2324 \\
\hline Thinking & 2.50 & 0.69 & 2.46 & 0.52 & 2.20 & 1.02 & 2.60 & 0.80 & 0.5699 \\
\hline Personality & 3.38 & 0.86 & 3.15 & 0.17 & 2.49 & 1.25 & 1.63 & 0.82 & $\mathbf{0 . 0 0 2 0}$ \\
\hline Mood & 3.25 & 1.04 & 2.55 & 0.62 & 2.51 & 0.99 & 2.66 & 0.10 & 0.2443 \\
\hline Family roles & 2.63 & 0.52 & 2.85 & 0.17 & 2.40 & 1.21 & 2.80 & 0.42 & 0.9436 \\
\hline Social roles & 1.63 & 0.52 & 2.52 & 0.31 & 2.09 & 0.86 & 2.00 & 0.85 & $\mathbf{0 . 0 3 6 4}$ \\
\hline Energy & 2.13 & 0.17 & 2.54 & 0.52 & 2.33 & 0.99 & 1.70 & 0.48 & 0.1176 \\
\hline Overall quality of life & 2.49 & 0.70 & 2.78 & 0.19 & 2.68 & 0.92 & 2.35 & 1.06 & 0.4100 \\
\hline
\end{tabular}


drawn from the study by Zawadzka et al. The results of the authors' own research and of the study by Zawadzka showed that quality of life connected with work and with upper extremity function was decreasing significantly along with the growing age of the patients. Furthermore, in the authors' own research it was observed that quality of life was significantly lower in people aged 61-70 than in other age groups, with respect to thinking (1.97), mood (2.29) and family roles (1.98).

Furthermore, the statistical analysis showed that the patients after ischemic stroke had significantly higher quality of life than patients after hemorrhagic stroke. These differences pertained to quality of life in the following spheres: self-care (2.88), vision (3.59), language (3.37), mobility (3.04), thinking (2.50), personality (3.03), mood (2.79), family roles (2.75) and energy (2.55). Moreover, the overall quality of life was significantly higher among people after ischemic stroke (2.83) than after hemorrhagic stroke (2.23). This correlation was confirmed in a study by A. Bielecki et al. [20] which revealed that patients after hemorrhagic stroke assessed their fitness worse (especially with respect to self-care and mobility) than patients after ischemic stroke.

\section{SUMMARY AND CONCLUSIONS}

The problem of patients after stroke is not only limitation of mobility due to paresis. Deficits originating in patients' psyche create huge discomfort. Identification of bio-psycho-social disorders and help in overcoming them can radically change the patient's situation [21].
Assessment of quality of life of post-stroke patients encompasses many spheres of life, interpreted subjectively. However, it is an indispensable task because it enables assessment of the patient's condition, not only in terms of effectiveness of therapy, but above all in terms of a possibility for improvement of the patient's quality of functioning, in the mental and social aspects.

The analysis of the research results indicated that:

1. The overall quality of life of the respondents was at the level of 2.64 points and was below the average established in the middle of the 1-5 point scale, that is 3 points.

2. The overall quality of life of the patients did not depend significantly on the time which passed since stroke.

3 . The overall quality of life was higher among women (3.02) than among men (2.39).

4. Ischemic stroke occurred in $67.5 \%$ of the patients. Other patients (32.5\%) had hemorrhagic stroke.

5. The patients after ischemic stroke had significantly higher quality of life (at the level of 2.83) than patients after hemorrhagic stroke (at the level of 2.23).

6. The majority of the respondents $(67.5 \%)$ stated that there was no chance to return to the previously pursued occupation.

7. The majority of the patients (95.0\%) did not resume professional activity after stroke.

8. As a result of rehabilitation, motor activity was improved in $53.8 \%$ of the respondents and mental condition was enhanced in $51.3 \%$ of the patients who actively participated in rehabilitation exercises.

\section{Ocena jakości życia pacjentów po przebytym udarze mózgu}

\section{WPROWADZENIE}

Zainteresowanie jakością życia pojawiło się w latach 70. XX wieku za sprawą Cambella, uznawanego za pioniera badań nad jakością życia. Natomiast samo pojęcie jakości życia pojawiło się w roku 1990 [1]. Wielowymiarowe ujęcie jakości życia odnajdujemy w definicji Światowej Organizacji Zdrowia. Według Światowej Organizacji Zdrowia (WHO) jakość życia to postrzeganie przez jednostkę jej pozycji życiowej, w kontekście systemów wartości oraz kultury w jakiej żyje, relacji do jej celów, oczekiwań, standardów i zainteresowań [2].

$\mathrm{Na}$ podstawie przytoczonej definicji jakości życia zaproponowanej przez WHO do zakresu oceny jakości życia włączono obok stanu fizycznego również psychiczny, relacje społeczne, środowisko, religię, wierzenia i przekonania. [3]. Ocenę jakości życia można traktować jako obraz sytuacji życiowej człowieka, który odnosi się do jego fragmentu życia i porównuje się go do określonego wzorca, który jest przedmiotem jego pragnień. Również jest to różnica pomiędzy nadziejami i oczekiwaniami, a obecnymi doświadczeniami danej osoby.
Badanie jakości życia jest zagadnieniem interdyscyplinarnym, łączącym aspekty kliniczne z psychologicznymi. Istotne stają się cele służące poprawie komfortu życia pacjenta $\mathrm{z}$ chorobą. Przebycie udaru obniża jakość życia w wymiarze funkcjonalnym i psychicznym. Koncentracja na wynikach terapeutycznych nie jest jedynym $\mathrm{z}$ celów leczenia. Powodem tego jest realizacja tzw. celów pozamedycznych, przez które rozumie się poprawę samopoczucia chorego, wpływającego na jego funkcjonowanie w społeczeństwie.

Obniżona jakość życia jest efektem uszkodzenia ośrodkowego układu nerwowego, a tym samym powoduje obniżenie samodzielności w wykonywaniu czynności życia codziennego i prowadzi do inwalidztwa, a także zależności od innych osób. Obniżenie jakości życia po udarze mózgu spowodowane jest głównie poprzez zmniejszenie sprawności fizycznej, zaburzenia emocjonalne, a także brak wsparcia społecznego. Kłopoty z samodzielnym wykonaniem podstawowych czynności życiowych, niekiedy utrata dotychczasowego statusu społecznego, brak oparcia w rodzinie, powodują narastającą izolację chorego od 
świata zewnętrznego i ograniczenie kontaktów społecznych. Rozpoznanie wszystkich ograniczeń i pomoc pacjentowi w przezwyciężaniu jego problemów może diametralnie zmienić sytuację chorego [4].

Dokonany przez autorów przegląd opublikowanych prac oraz badania własne dotyczące jakości życia osób po udarze otwierają drogę do dalszych wieloaspektowych analiz. W badaniu jakości życia należy brać pod uwage aspekty fizyczne, psychologiczne, a także relacje społeczne i środowiskowe.

\section{CEL PRACY}

Celem głównym pracy była analiza jakości życia pacjentów po udarze mózgu leczonych na Oddziale Neurologii w Powiatowym Szpitalu Specjalistycznym.

Jakość życia analizowano w kontekście wpływu czynników społeczno-demograficznych, rodzaju udaru mózgu, typu niedowładu, czasu rehabilitacji oraz czasu jaki upłynał od wystąpienia udaru.

\section{MATERIAŁ I METODYKA}

Do badań zakwalifikowano grupę 80 pacjentów leczonych w Szpitalu Specjalistycznym na Oddziale Neurologii. Badanie zostało przeprowadzone w okresie od kwietnia do maja 2017 roku. Część respondentów wypełniała ankiety samodzielnie bez udziału ankietera, nieliczni z pomoca ankietera. Kryterium doboru do badań stanowiło przebycie udaru mózgu, kwalifikowane na podstawie dokumentacji medycznej. Respondenci zostali poinformowani, jaki jest cel przeprowadzanych badań. Każda z osób wyraziła pisemną zgodę na badanie. Przed przeprowadzeniem badań uzyskano również zgodę dyrektora szpitala. W procesie badawczym przestrzegano zapisów Deklaracji Helsińskiej.

W pracy wykorzystano polską wersję kwestionariusza ankiety Skali Jakości Życia po Udarze Mózgu (SJŻUM), autorstwa Williams i wsp. z Indiana University School of Medicine w Indianapolis, [5]. Adaptację kulturową skali w wersji polskiej przeprowadzili A. Bejer i A. Kwolek [6].

Skala umożliwia uzyskanie profilu jakości życia w zakresie dwunastu podskal, tj.: samoobsługa (S; ang. $S$ ), wzrok (W; ang. $V$ ), mowa (MA; ang. L), mobilność (MĆ; ang. M), praca (P; ang.W), funkcja kończyn górnych (FKG; ang. UE), myślenie (ME; ang. T), osobowość (O; ang. $P$ ), nastrój $(\mathrm{N}$; ang. $M)$, role w rodzinie (RR; ang. $F R)$, role społeczne (RS; ang.SR), energia (E; ang. E). Każda z podskal zawiera od trzech do sześciu pozycji, łącznie jest ich 49. SJŻUM posiada dwa zestawy odpowiedzi, które powinny być udzielane adekwatnie do stanu zaobserwowanego przez pacjenta $\mathrm{w}$ tygodniu poprzedzającym badanie. Skala obejmowała 12 podskal oraz wynik ogólny, z których wszystkie mieściły się zakresie 5-stopniowej skali Likerta, gdzie wyższy wynik świadczy o lepszej funkcji $[5,6,7]$.

Analiza materiału badawczego została wykonana za pomocą testów statystycznych Manna-Whitneya oraz Kruskala-Wallisa. Przyjęto poziom istotności $\mathrm{p}<0,05$. Obliczenia przeprowadzono z użyciem programu statystycznego IBM SPSS Statictics 24.0 PL.

\section{WYNIKI BADAŃ}

Badana grupa liczyła 80 pacjentów. Ponad połowę (61,3\%) stanowili mężczyźni (49 mężczyzn). 31 kobiet biorących udział w badaniu, co stanowiło odpowiednio 38,8\% badanych. Większość respondentów (73,8\%), to osoby w wieku senioralnym. Najliczniejszą grupę wiekową stanowiły osoby między 61 a 70 rokiem życia (43,8\%). Od 71 do 80 lat miało $22,5 \%$ badanych, a $16,3 \%$ osób było w grupie wiekowej 41-50 lat. Nieliczne osoby miały od 51 do 60 lat $(7,5 \%), 81-90$ lat $(7,5 \%)$ lub 30-40 lat $(2,5 \%)$.

Ogólna jakość życia badanych była na poziomie 2,64 pkt. $(\mathrm{SD}=0,84)$. Wyniki wahały się w zakresie $1,08-4,42$ pkt., a połowa osób uzyskała poniżej 2,98 pkt. Ogólna jakość życia była poniżej wartości przeciętnej, za którą przyjęto środek skali 1-5 pkt., tj. 3 pkt. Przedstawia to tab. 1 .

Tab. 1. Jakość życia badanych.

\begin{tabular}{|l|c|c|c|c|c|}
\hline & Średnia & Mediana & SD & Min. & Maks. \\
\hline Samoobsługa & 2,69 & 3,00 & 1,03 & 1,00 & 4,60 \\
\hline Wzrok & 3,26 & 3,00 & 1,05 & 2,00 & 5,00 \\
\hline Mowa & 3,13 & 3,00 & 1,04 & 1,25 & 5,00 \\
\hline Mobilność & 2,84 & 3,00 & 1,03 & 1,00 & 5,00 \\
\hline Praca & 2,70 & 3,00 & 0,99 & 1,00 & 4,33 \\
\hline $\begin{array}{l}\text { Funkcja kończyn } \\
\text { górnych }\end{array}$ & 2,58 & 2,20 & 1,11 & 1,00 & 4,60 \\
\hline Myślenie & 2,32 & 2,33 & 0,90 & 1,00 & 4,00 \\
\hline Osobowó́ć & 2,58 & 3,00 & 1,15 & 1,00 & 5,00 \\
\hline Nastrój & 2,61 & 2,60 & 0,89 & 1,00 & 4,80 \\
\hline Role rodzinne & 2,55 & 3,00 & 0,99 & 1,00 & 5,00 \\
\hline Role społeczne & 2,11 & 2,20 & 0,79 & 1,00 & 4,60 \\
\hline Energia & 2,26 & 2,33 & 0,85 & 1,00 & 4,33 \\
\hline Ogólna jakó́ćć̀cia & 2,64 & 2,98 & 0,84 & 1,08 & 4,42 \\
\hline
\end{tabular}

Najwyższą jakość życia pacjenci po udarze mózgu mieli w zakresie wzroku $(3,26)$. Na poziomie przeciętnym była jakość życia związana $\mathrm{z}$ mową $(3,13)$ oraz mobilnością $(2,84)$. Istotnie obniżoną jakość życia mieli pacjenci po udarze mózgu w zakresie samoobsługi $(2,69)$, nastroju $(2,61)$, osobowości $(2,58)$, funkcji kończyn górnych $(2,58)$, ról rodzinnych $(2,55)$. Najbardziej obniżoną jakość życia badani prezentowali w zakresie myślenia $(2,32)$, energii $(2,26)$ oraz ról społecznych $(2,11)$.

Analizując jakość życia z uwzględnieniem płci badanych, wykazano, że kobiety prezentowały istotnie wyższą jakość życia w porównaniu do mężczyzn w takich wymiarach jak: samoobsługa $(3,06)$, wzrok $(3,70)$, mobilność $(3,32)$, praca $(3,11)$, funkcja kończyn górnych $(3,05)$, myślenie $(2,69)$, role rodzinne $(3,01)$, role społeczne $(2,51)$ oraz energia $(2,60)$. Również ogólna jakość życia była wyższa wśród kobiet $(3,02)$ niż wśród mężczyzn $(2,39)$. Przedstawia to tab. 2. 
Tab. 2. Jakość życia a płeć badanych.

\begin{tabular}{|l|c|c|c|c|c|}
\hline \multirow{2}{*}{ Płeć } & \multicolumn{2}{|c|}{ Kobieta } & \multicolumn{2}{c|}{ Mężczyzna } & \multirow{2}{*}{ p } \\
\cline { 2 - 5 } & Średnia & SD & Średnia & SD & \\
\hline Samoobsługa & 3,06 & 0,96 & 2,46 & 1,02 & $\mathbf{0 , 0 3 0 2}$ \\
\hline Wzrok & 3,70 & 0,83 & 2,99 & 1,08 & $\mathbf{0 , 0 0 2 4}$ \\
\hline Mowa & 3,43 & 0,75 & 2,95 & 1,15 & 0,0555 \\
\hline Mobilność & 3,32 & 0,92 & 2,53 & 0,99 & $\mathbf{0 , 0 0 6 4}$ \\
\hline Praca & 3,11 & 0,84 & 2,44 & 1,00 & $\mathbf{0 , 0 0 3 1}$ \\
\hline Funkcja kończyn górnych & 3,05 & 1,08 & 2,28 & 1,03 & $\mathbf{0 , 0 0 5 7}$ \\
\hline Myślenie & 2,69 & 0,75 & 2,09 & 0,92 & $\mathbf{0 , 0 0 6 2}$ \\
\hline Osobowość & 3,02 & 0,86 & 2,30 & 1,23 & 0,0825 \\
\hline Nastrój & 2,76 & 0,79 & 2,52 & 0,95 & 0,5681 \\
\hline Role rodzinne & 3,01 & 0,60 & 2,25 & 1,07 & $\mathbf{0 , 0 0 0 2}$ \\
\hline Role społeczne & 2,51 & 0,76 & 1,85 & 0,70 & $\mathbf{0 , 0 0 0 9}$ \\
\hline Energia & 2,60 & 0,53 & 2,05 & 0,94 & $\mathbf{0 , 0 2 7 2}$ \\
\hline Ogólna jakość życia & 3,02 & 0,63 & 2,39 & 0,87 & $\mathbf{0 , 0 0 1 9}$ \\
\hline
\end{tabular}

Wraz z wiekiem pacjentów zmniejszała się istotnie jakość życia związana $\mathrm{z}$ pracą $(\mathrm{p}<0,05)$ oraz funkcją kończyn górnych $(\mathrm{p}<0,05)$. Osoby w wieku 61-70 lat miały istotnie $\mathrm{w}$ większym stopniu niż pozostali badani obniżoną jakość życia w zakresie myślenia $(1,97)$, nastroju $(2,29)$, ról rodzinnych $(1,98)$. Nie stwierdzono natomiast, by ogólna jakość życia pacjentów zależała istotnie od ich wieku.

Istotną kwestią zapewniającą wysoką jakość życia jest również sytuacja zawodowa. Większość badanych $(67,5 \%)$ deklarowała brak możliwości powrotu do wcześniej wykonywanego zawodu. Minimalną szansę powrotu do wcześniej wykonywanego zawodu widziało 31,3\% pacjentów, a tylko $1,3 \%$ badanych dobrze oceniło swoją sytuację zawodową. Przedstawia to ryc. 1.

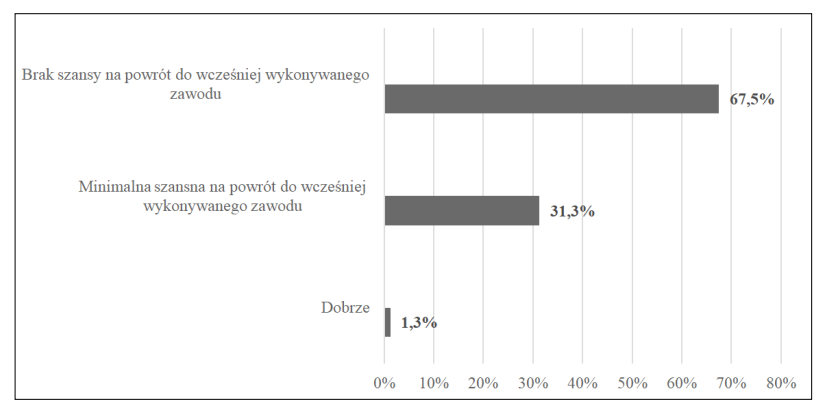

Ryc 1. Samoocena sytuacji zawodowej.

Większość pacjentów $(95,0 \%)$ nie wróciła po udarze do aktywności zawodowej.

W ciągu 1 miesiąca po udarze, wróciło do aktywności zawodowej 1,3\% osób, a w okresie powyżej 1 roku 3,8\% badanych. Przedstawia to ryc. 2 .

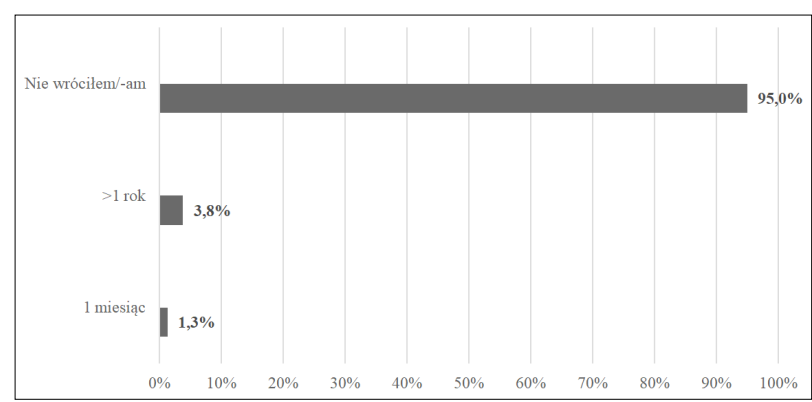

Udar niedokrwienny wystąpił w przypadku $67,5 \%$ pacjentów. Natomiast w pozostałej grupie, czyli u 32,5\% osób wystąpił udar krwotoczny. U połowy chorych $(50,0 \%)$ wystąpił udar prawostronny, a u pozostałych osób udar lewostronny. Dla większości pacjentów $(63,8 \%)$ był to pierwszy udar mózgu. Drugi udar mózgu przeszło $28,8 \%$ osób, a trzeci 7,5\% badanych.

Analiza statystyczna wykazała również, że pacjenci po udarze niedokrwiennym posiadali istotnie wyższą jakość życia niż pacjenci po udarze krwotocznym. Różnice te dotyczyły jakości życia w zakresie: samoobsługi $(2,88)$, wzroku $(3,59)$, mowy $(3,37)$, mogilności $(3,04)$, myślenia $(2,50)$, osobowości $(3,03)$, nastroju $(2,79)$, ról rodzinnych $(2,75)$ oraz energii $(2,55)$. Odnotowano również istotnie wyższą ogólną jakość życia wśród osób po udarze niedokrwiennym $(2,83)$ niż po udarze krwotocznym $(2,23)$. Przedstawia to tab. 3.

Tab. 3. Jakość życia a rodzaj udaru mózgu.

\begin{tabular}{|l|c|c|c|c|c|}
\hline \multirow{2}{*}{ Rodzaj udaru mózgu } & \multicolumn{2}{|c|}{ Niedokrwienny } & \multicolumn{2}{c|}{ Krwotoczny } & \multirow{2}{*}{ p } \\
\cline { 2 - 5 } & Średnia & SD & Średnia & SD & \\
\hline Samoobsługa & 2,88 & 0,94 & 2,30 & 1,13 & $\mathbf{0 , 0 0 9 5}$ \\
\hline Wzrok & 3,59 & 0,89 & 2,58 & 1,03 & $<\mathbf{0 , 0 0 0 1}$ \\
\hline Mowa & 3,37 & 0,98 & 2,64 & 0,99 & $\mathbf{0 , 0 0 1 0}$ \\
\hline Mobilność & 3,04 & 0,86 & 2,42 & 1,24 & $\mathbf{0 , 0 2 7 2}$ \\
\hline Praca & 2,85 & 0,86 & 2,40 & 1,19 & 0,0906 \\
\hline Funkcja kończyn & 2,64 & 1,04 & 2,44 & 1,25 & 0,2645 \\
\hline górnych & 2,50 & 0,77 & 1,95 & 1,04 & $\mathbf{0 , 0 1 3 4}$ \\
\hline Myślenie & 3,03 & 0,91 & 1,64 & 1,04 & $<\mathbf{0 , 0 0 0 1}$ \\
\hline Osobowość & 2,79 & 0,82 & 2,25 & 0,95 & $\mathbf{0 , 0 0 4 7}$ \\
\hline Nastrój & 2,75 & 0,83 & 2,12 & 1,14 & $\mathbf{0 , 0 0 5 6}$ \\
\hline Role rodzinne & 2,17 & 0,69 & 1,98 & 0,97 & 0,2067 \\
\hline Role społeczne & 2,55 & 0,64 & 1,67 & 0,93 & $<\mathbf{0 , 0 0 0 1}$ \\
\hline Energia & 2,83 & 0,69 & 2,23 & 0,98 & $\mathbf{0 , 0 0 9 4}$ \\
\hline Ogólna jakó́ćċycia & & & & &
\end{tabular}

W badaniach dokonano również oceny jakości życia pod względem samodzielności pacjentów. Samodzielnym w zakresie zaspokajania potrzeb fizjologicznych było $41,3 \%$ pacjentów. Z pomocą drugiej osoby wychodziło do toalety $58,8 \%$ badanych. Przedstawia to ryc. 3 .

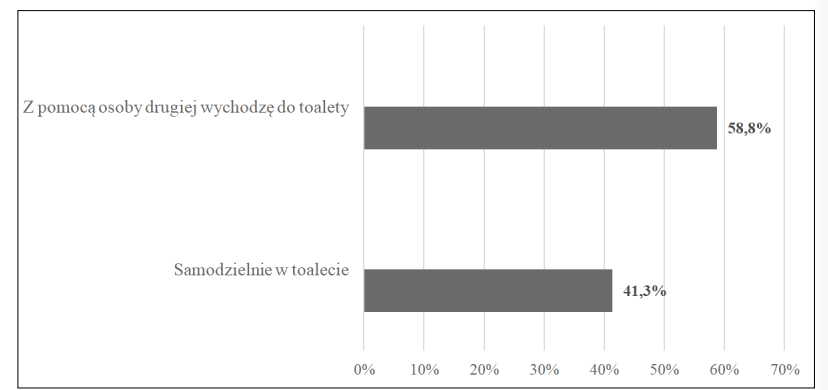

Ryc 3. Samodzielność w radzeniu sobie z zaspokajaniem potrzeb fizjologicznych. 
Jakość życia w zakresie samoobsługi może zostać poprawiona dzięki rehabilitacji. Grupa $41,3 \%$ badanych ćwiczyła systematycznie z pomocą rodziny. Natomiast systematycznie samodzielnie ćwiczyło 30,0\% osób, a 28,8\% pacjentów ćwiczyło $\mathrm{z}$ rehabilitantem.

Pacjenci, którzy ćwiczyli cały czas z pomocą rodziny posiadali istotnie wyższą jakość życia w zakresie wzroku $(3,79)$, mowy $(3,73)$, mobilności $(3,10)$, funkcji kończyn górnych $(2,86)$, myślenia $(2,68)$, nastroju $(2,96)$, ról rodzinnych $(3,01)$ oraz energii $(2,58)$ w porównaniu do osób ćwiczących samodzielnie lub $\mathrm{z}$ rehabilitantem. Ogólna jakość życia była również wyższa u pacjentów ćwiczących cały czas z rodziną $(2,93)$, niż u osób ćwiczących samodzielnie $(2,45)$ lub z rehabilitantem $(2,40)$ Prezentuje to tab. 4.

Tab. 4. Jakość życia badanych a długość rehabilitacji.

\begin{tabular}{|l|c|c|c|c|c|c|c|}
\hline \multirow{2}{*}{$\begin{array}{l}\text { Długość } \\
\text { rehabilitacji }\end{array}$} & \multicolumn{2}{|c|}{$\begin{array}{c}\text { Ćwizęcały cas } \\
\text { zrehabilitantem }\end{array}$} & \multicolumn{2}{c|}{$\begin{array}{c}\text { Ćwiczę cały } \\
\text { czas z pomoca } \\
\text { rodziny }\end{array}$} & \multicolumn{2}{c|}{$\begin{array}{c}\text { Ćwiczę } \\
\text { cały czas } \\
\text { samodzielnie }\end{array}$} & \multirow{2}{*}{ p } \\
\cline { 2 - 7 } & Średnia & SD & Średnia & SD & Średnia & SD & \\
\hline Samoobsługa & 2,56 & 0,99 & 2,92 & 1,15 & 2,50 & 0,88 & 0,1331 \\
\hline Wzrok & 3,00 & 0,78 & 3,79 & 1,17 & 2,79 & 0,78 & $\mathbf{0 , 0 0 1 1}$ \\
\hline Mowa & 2,65 & 0,57 & 3,73 & 0,99 & 2,78 & 1,06 & $\mathbf{0 , 0 0 0 2}$ \\
\hline Mobilność & 2,63 & 0,88 & 3,10 & 1,09 & 2,67 & 1,04 & $\mathbf{0 , 0 2 7 3}$ \\
\hline Praca & 2,54 & 0,82 & 2,84 & 1,06 & 2,67 & 1,05 & 0,3280 \\
\hline $\begin{array}{l}\text { Funkcja kończyn } \\
\text { górnych }\end{array}$ & 2,02 & 0,61 & 2,86 & 1,26 & 2,73 & 1,10 & $\mathbf{0 , 0 4 1 6}$ \\
\hline Myślenie & 2,03 & 0,83 & 2,68 & 0,77 & 2,11 & 1,00 & $\mathbf{0 , 0 1 0 8}$ \\
\hline Osobowość & 2,55 & 1,05 & 2,74 & 1,10 & 2,39 & 1,33 & 0,4506 \\
\hline Nastrój & 2,17 & 1,00 & 2,96 & 0,47 & 2,55 & 1,06 & $\mathbf{0 , 0 0 2 6}$ \\
\hline Role rodzinne & 2,35 & 1,00 & 3,01 & 0,79 & 2,10 & 0,98 & $\mathbf{0 , 0 0 0 7}$ \\
\hline Role społeczne & 2,23 & 0,78 & 2,15 & 0,70 & 1,93 & 0,90 & 0,5069 \\
\hline Energia & 2,19 & 0,90 & 2,58 & 0,69 & 1,90 & 0,87 & $\mathbf{0 , 0 0 3 2}$ \\
\hline $\begin{array}{l}\text { Ogólna jakość } \\
\text { życia }\end{array}$ & 2,40 & 0,73 & 2,93 & 0,77 & 2,45 & 0,93 & $\mathbf{0 , 0 0 4 8}$ \\
\hline
\end{tabular}

Wysoki odsetek respondentów nie uczestniczył w ćwiczeniach rehabilitacyjnych. Czynnikiem wpływającym na brak chęci do podejmowania udziału w ćwiczeniach było najczęściej zniechęcenie (25,0\%). Na drugim miejscu znalazło się zmęczenie (17,5\%), na trzecim depresja (16,3\%). Brak wiary w powrót do zdrowia wskazało 12,5\% osób, a niechęć do obarczania pozostałych domowników swoją niepełnosprawnością wymieniło 10,0\% pacjentów. Z zaangażowaniem brało udział w rehabilitacji jedynie $18,8 \%$ badanych. Prezentuje to ryc. 4 .

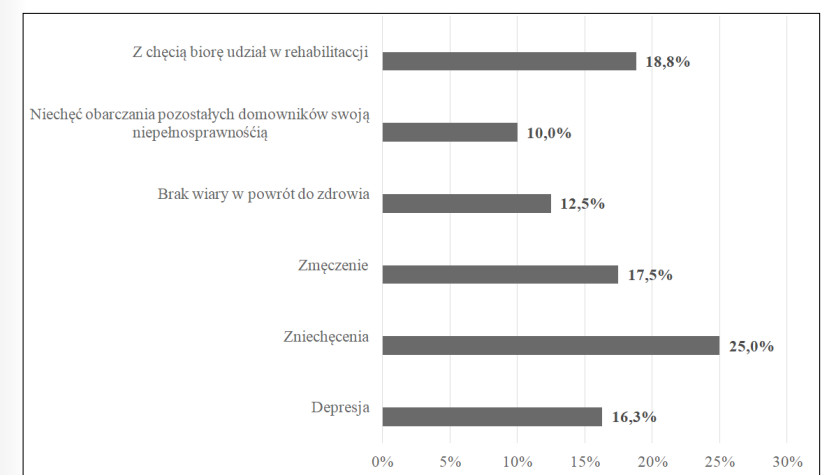

Ryc 4. Czynniki wpływające na brak chęci podejmowania udziału w ćwiczeniach.
Respondentom, którzy podejmowali wysiłek związany z rehabilitacją, zadano również pytanie o skuteczność rehabilitacji. 83,8\% badanych udzieliło odpowiedzi twierdzącej. Poprawa motoryki w wyniku rehabilitacji nastąpiła u 53,8\% osób, a poprawa psychiki u 51,3\% pacjentów biorących czynny udział w ćwiczeniach rehabilitacyjnych. Nieliczni wskazali brak jakiejkolwiek poprawy w wyniku rehabilitacji $(6,3 \%)$ lub poprawę wszystkich aspektów funkcjonowania. Wyniki nie sumowały się do 100\%, ponieważ badani wskazywali więcej niż jedną odpowiedź. Prezentuje to ryc. 5 .

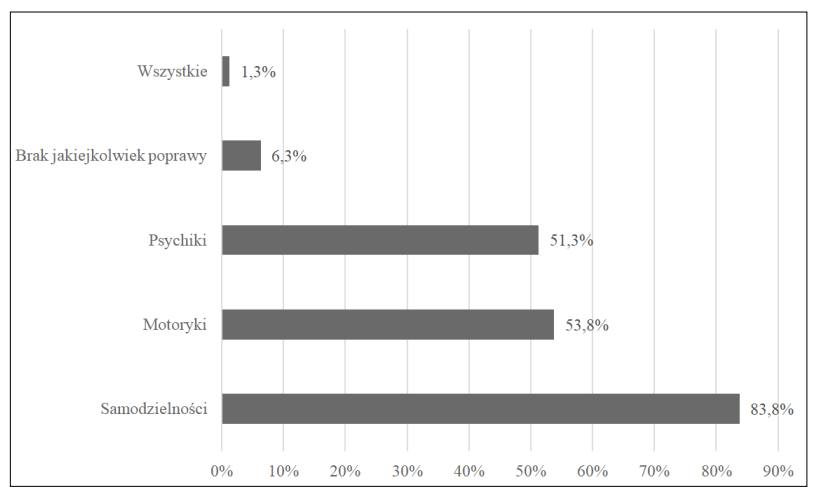

Ryc 5. Wpływ rehabilitacji na poprawę wybranych aspektów funkcjonowania.

Liczne badania wskazują, że czynnikiem determinującym jakość życia po udarze, jest czas, który minął od wystąpienia udaru $[8,9]$. W przypadku $10,0 \%$ pacjentów od wystąpienia udaru minęło 8-14 dni. W grupie 16,3\% osób było to 15-30 dni. Najczęściej (61,3\%) od wystąpienia udaru minęło 31-90 dni. Powyżej 90 dni od wystąpienia udaru minęło w grupie $12,5 \%$ pacjentów. Badania własne dowiodły, że jakość życia pacjentów istotnie zmniejszała się wraz z upływem czasu w zakresie osobowości. Najwyższą jakość życia w tej dziedzinie miały osoby, u których od wystąpienia udaru minęło 8-14 dni $(3,38)$, najniższą badani, u których minęło powyżej 90 dni $(1,63)$. Pacjenci, u których od wystąpienia udaru minęło 8-14 dni posiadali istotnie niższą jakość życia w zakresie pełnienia ról społecznych $(1,63)$ w porównaniu do pozostałych badanych, u których minął dłuższy okres od wystąpienia udaru. Jednak ogólna jakość życia pacjentów nie zależała istotnie od czasu, który minął od wystąpienia udaru. Prezentuje to tab. 5 .

\section{DYSKUSJA}

Następstwem udaru mózgu są liczne powikłania, głównie są to deficyty neurologiczne [10]. U części pacjentów udar mózgu jest odwracalny i nie pozostawia żadnych powikłań, jednakże u około $25 \%$ prowadzi do trwałej niepełnosprawności oraz obniżenia jakości życia [11]. Powikłaniem, które wpływa w największym stopniu na obniżenie poziomu jakość życia pacjentów po udarze mózgu jest niesprawność ruchowa, głównie w wyniku porażenia połowiczego, nieprawidłowego rozkładu napięcia mięśniowego. Zapobiegać im można poprzez wcześnie podjętą i prawidłowo prowadzoną rehabilitację [12]. Jakość życia może zostać poprawiona dzięki rehabilitacji, 
Tab. 5. Jakość życia a czas, który minął od wystąpienia udaru.

\begin{tabular}{|c|c|c|c|c|c|c|c|c|c|}
\hline \multirow{2}{*}{$\begin{array}{l}\text { Czas, który minął } \\
\text { od wystąpienia udaru }\end{array}$} & \multicolumn{2}{|c|}{$8-14 \mathrm{dni}$} & \multicolumn{2}{|c|}{$15-30 \mathrm{dni}$} & \multicolumn{2}{|c|}{$31-90 \mathrm{dni}$} & \multicolumn{2}{|c|}{ Powyżej 90 dni } & \multirow{2}{*}{ p } \\
\hline & Średnia & SD & Średnia & SD & Średnia & SD & Średnia & SD & \\
\hline Samoobsługa & 2,48 & 0,72 & 2,92 & 1,04 & 2,73 & 0,88 & 2,38 & 1,79 & 0,5240 \\
\hline Wzrok & 2,88 & 0,17 & 3,46 & 0,52 & 3,31 & 1,14 & 3,10 & 1,45 & 0,4200 \\
\hline Mowa & 2,63 & 0,52 & 3,00 & 0,00 & 3,32 & 1,18 & 2,80 & 1,07 & 0,2077 \\
\hline Mobilność & 2,31 & 0,95 & 3,08 & 0,09 & 2,99 & 1,00 & 2,20 & 1,55 & 0,0854 \\
\hline Praca & 2,25 & 1,04 & 3,00 & 0,00 & 2,80 & 0,94 & 2,20 & 1,55 & 0,3448 \\
\hline Funkcja kończyn górnych & 2,25 & 1,04 & 2,09 & 0,10 & 2,83 & 1,10 & 2,22 & 1,63 & 0,2324 \\
\hline Myślenie & 2,50 & 0,69 & 2,46 & 0,52 & 2,20 & 1,02 & 2,60 & 0,80 & 0,5699 \\
\hline Osobowość & 3,38 & 0,86 & 3,15 & 0,17 & 2,49 & 1,25 & 1,63 & 0,82 & 0,0020 \\
\hline Nastrój & 3,25 & 1,04 & 2,55 & 0,62 & 2,51 & 0,99 & 2,66 & 0,10 & 0,2443 \\
\hline Role rodzinne & 2,63 & 0,52 & 2,85 & 0,17 & 2,40 & 1,21 & 2,80 & 0,42 & 0,9436 \\
\hline Role społeczne & 1,63 & 0,52 & 2,52 & 0,31 & 2,09 & 0,86 & 2,00 & 0,85 & 0,0364 \\
\hline Energia & 2,13 & 0,17 & 2,54 & 0,52 & 2,33 & 0,99 & 1,70 & 0,48 & 0,1176 \\
\hline Ogólna jakość życia & 2,49 & 0,70 & 2,78 & 0,19 & 2,68 & 0,92 & 2,35 & 1,06 & 0,4100 \\
\hline
\end{tabular}

na co wskazuja badania Hopman i wsp. [13]. W badaniach własnych odnotowano, że w wyniku rehabilitacji nastąpiła poprawa motoryki u 53,8\% osób, oraz poprawa psychiki u 51,3\% pacjentów biorących czynny udział w ćwiczeniach rehabilitacyjnych. Nieliczni wskazali brak jakiejkolwiek poprawy w wyniku rehabilitacji $(6,3 \%)$ lub poprawę wszystkich aspektów funkcjonowania.

Ogólna jakość życia pacjentów nie zależała istotnie od czasu, który minął od wystapienia udaru. Aschilo w swoich badaniach na grupie 96 chorych po udarze mózgu stwierdził, że u 77 chorych następowało ciągłe i stałe pogorszenie jakości życia [14]. Natomiast Niemi i wsp. zaobserwowali spadek jakości życia po upływie pewnego czasu od wystąpienia udaru mózgu. [15]. Na podstawie badań J. Rykały i wsp., duży wpływ na jakość życia osób po udarze mózgu mają konsekwencje wynikające $\mathrm{z}$ uszkodzenia OUN, ale także czas, jaki upłynął od dokonania się udaru [16].

Analiza wyników badań wykazała, że jakość życia po udarze mózgu była wyższa wśród kobiet niż wśród mężczyzn. Do podobnych wniosków prowadzą badania Baumann i wsp. Oceniając jakość życia 94 pacjentów po udarze mózgu - obywateli Luksemburga za pomocą kwestionariusza Newsqol wykazali istotnie lepszą jakość życia kobiet [17]. Natomiast w badaniach Zawadzkiej i wsp. [18], z wykorzystaniem skali SJŻUM, wykazano, że płeć nie wpływa znamiennie na jakość życia po udarze mózgu w żadnym $\mathrm{z}$ analizowanych obszarów. Natomiast badania Carod-Artal i wsp. przy użyciu skali SIP, wskazują na gorszą jakość życia kobiet w Hiszpanii, które jednakże wykazują się gorszym stanem neurologicznym i funkcjonalnym oraz bardziej zaawansowanym wiekiem w porównaniu do mężczyzn [19].

W kontekście analizy jakości życia uzależnionej od wieku pacjenta, podobne wnioski płyną z badań Zawadzkiej i wsp. Wyniki badań własnych oraz Zawadzkiej, wskazały, że wraz z wiekiem pacjentów zmniejszała się istotnie jakość życia związana z pracą oraz funkcją kończyn górnych. Dodatkowo w badaniach własnych dostrzeżono, że osoby w wieku 61-70 lat miały w istotnie większym stopniu niż pozostali badani obniżoną jakość życia w zakresie myślenia $(1,97)$, nastroju $(2,29)$, ról rodzinnych $(1,98)$.
Analiza statystyczna wykazała również, że pacjenci po udarze niedokrwiennym posiadali istotnie wyższą jakość życia niż pacjenci po udarze krwotocznym. Różnice te dotyczyły jakości życia w zakresie: samoobsługi $(2,88)$, wzroku $(3,59)$, mowy $(3,37)$, mobilności $(3,04)$, myślenia $(2,50)$, osobowości $(3,03)$, nastroju $(2,79)$, ról rodzinnych $(2,75)$ oraz energii $(2,55)$. Odnotowano również istotnie wyższą ogólną jakość życia wśród osób po udarze niedokrwiennym $(2,83)$ niż po udarze krwotocznym $(2,23)$. Potwierdzeniem tej zależności są badania A. Bieleckiego i wsp. [20], w których wykazano, że pacjenci po udarach krwotocznych gorzej oceniają swoją sprawność (zwłaszcza dotyczy to samoobsługi i poruszania się) niż chorzy po udarze niedokrwiennym.

\section{PODSUMOWANIE I WNIOSKI}

Problemem chorych po udarze mózgu jest nie tylko ograniczenie sprawności ruchowej będące następstwem niedowładu. Deficyty powstające w psychice chorych stwarzają ogromny dyskomfort. Identyfikacja zaburzeń bio-psycho-społecznych i pomoc w ich przezwyciężaniu może diametralnie zmienić sytuację chorego [21]. Ocena jakości życia osób po udarze mózgu, obejmuje wiele obszarów życia interpretowanych subiektywnie. Jest to jednak zadanie konieczne, ponieważ umożliwia ocenę stanu chorego, nie tylko pod kątem skuteczności terapii, ale przede wszystkim pod względem możliwości poprawy jakości funkcjonowania chorego w aspekcie psychicznym oraz społecznym.

Analiza wyników badań wykazała, że:

1. Ogólna jakość życia badanych była na poziomie 2,64 pkt i była poniżej wartości przeciętnej, za którą przyjęto środek skali 1-5 pkt., tj. 3 pkt.

2. Ogólna jakość życia pacjentów nie zależała istotnie od czasu, który minął od wystąpienia udaru.

3. Ogólna jakość życia była wyższa wśród kobiet $(3,02)$ niż wśród mężczyzn $(2,39)$.

4. Udar niedokrwienny wystąpił w przypadku $67,5 \%$ pacjentów. W pozostałej grupie (32,5\% osób) wystąpił udar krwotoczny. 
5. Pacjenci po udarze niedokrwiennym posiadali istotnie wyższą jakość życia (na poziomie 2,83) niż pacjenci po udarze krwotocznym (na poziomie 2,23).

6. Większość badanych $(67,5 \%)$ deklarowała brak możliwości powrotu do wcześniej wykonywanego zawodu.

7. Większość pacjentów $(95,0 \%)$ nie wróciła po udarze do aktywności zawodowej.

8. W wyniku rehabilitacji nastąpiła poprawa motoryki u 53,8\% osób, oraz poprawa psychiki u 51,3\% pacjentów biorących czynny udział w ćwiczeniach rehabilitacyjnych.

\section{PIŚMIENNICTWO/REFERENCES}

1. Kukielczak A. Rozwój zainteresowania w naukach medycznych badaniami nad jakością życia. Przegląd epid. 2012: 66, 539-554.

2. Kasprzak E. Poczucie jakości życia osób bezrobotnych pięć lat temu a obecnie. Badania porównawcze. [w:] Bańka A, red. Psychologia jakości życia. Poznań: WSWPS; 2005, s. 135-150.

3. Wołowicka L. Jakość życia w naukach medycznych. Poznań: Dział Wydawnictw Uczelnianych Akademii Medycznej im. Karola Marcinkowskiego; 2001.

4. Nowak S, Prędota-Panecka H, Błaszczyk B, i wsp. Czynniki ryzyka udarów mózgu w materiale własnym. Neurologia i Neurochirurgia Polska. 2005, 39(4): 228-229.

5. Williams LS, Weinberger M, Harris LE, et al. Development of Stroke-Specfic Quality of Life Scale. Stroke. 1999, 30: 1362-1369.

6. Bejer A, Kwolek. Polska adaptacja kulturowa skali Stroke-Specific Quality of Life. Postępy Rehabilitacji. 2009; 1: 41-46.

7. Bejer A. Validation analysis of polish version of the Stroke- Specific Quality of Life Scale. New clinimetrics methods in physiotherapy. Krakow-Rzeszow-Zamośc: Konsorcjum Akademickie; 2010, s. 163-183.

8. Mazur R, Świerkocka - Miastkowska M. Diagnostyka wczesnego okresu udaru mózgu. Choroby serca i naczyń. 2005; 2(3): 136.

9. Brola W, Węgrzyn W. Jakość życia po udarze mózgu. Studia Medyczne Akademii Świętokrzyskiej. 2006;3:161-167.
10. Kolan M. Zaburzenia funkcji poznawczych a choroby niedokrwienne mózgu. [w:] Nowakowski P, red. Neurokognitywistyka w patologii i zdrowiu. Szczecin: PUM; 2009-2011, s. 94-105.

11. Brola W, Fudala M, Przybylski W, Czernicki J, Profilaktyka późnych powikłań udaru mózgu. Studia Medyczne. 2008; 9: 21-26.

12. Kuczyńska-Zardzewiały A, Członkowska A. Co należy wiedzieć 0 udarze mózgu. Poradnik dla pacjentów i ich rodzin oraz wszystkich zainteresowanych. Sekcja Chorób Naczyniowych Polskiego Towarzystwa Neurologicznego. Broszura s. 16-18. www.fum.info.pl.

13. Hopman WM, Verner J. Quality of life during and after inpatient stroke rehabilitation. Stroke. 2003; 34: 801-805.

14. Maliszewska M. Czynniki ryzyka wystąpienia udarów niedokrwiennych mózgu. Przewodnik Lekarski. 2007; 7: 7-12.

15. Mazur R, Świerkocka - Miastkowska M. Diagnostyka wczesnego okresu udaru mózgu. Choroby serca i naczyń. 2005; 2(3): 136.

16. Rykała J, Kwolek A. Wpływ wybranych czynników na jakość życia oraz stan funkcjonalny pacjentów po udarze mózgu. Przegląd Medyczny Uniwersytetu Rzeszowskiego. 2009; 4:384-391.

17. Baumann M, Couffignal S, Le Bihan E, Chau N. Life satisfaction two-years after stroke onset: the effects of gender, sex occupational status, memory function and quality of life among stroke patients (Newsqol) and their family caregivers (Whoqol-bref) in Luxembourg. BMC Neurology. 2012;12(1):105-115.

18. Zawadzka J, Bejer A, Kwolek A. Wpływ wybranych czynników społecznodemograficznych na jakość życia pacjentów po udarze mózgu - doniesienie wstępne Przegląd Medyczny Uniwersytetu Rzeszowskiego i Narodowego Instytutu Leków w Warszawie. 2014; 1: 36-46.

19. Carod-Artal J, Egido JA, Gonzalez JL, de Seijas V. Quality of life among stroke survivors evaluated 1 year after stroke. Experience of a stroke unit. Stroke. 2000; 31: 2995-3000.

20. Bielecki A, Żmudzka-Wilczek E, Opara J, Mehlich K. Ocena jakości życia osób po udarze mózgu przy pomocy skali S.A.SIP 30. Część 1. Zeszyty MetodycznoNaukowe. Katowice: Wydawnictwo AWF. 2006; 20: 71-83.

21. Pasek J, Opara J, Pasek T, Sieroń A. Ocena czynności życia codziennego w zależności od podtypu przebytego udaru niedokrwiennego mózgu i przeprowadzonej wczesnej rehabilitacji. Udar Mózgu. 2009; 11(2): 41-49.

Praca przyjęta do druku/Manuscript received: 09.11.2017

Praca zaakceptowana do druku/Manuscript accepted: 25.04.2018

Tłumaczenie/Translation: Ewa Zabrotowicz 